\title{
The Polaroid and the Cross. Media-Reflexivity and Allegorical Figurations in Lucian Pintilie's The Oak (1992)
}

\author{
Katalin Sándor \\ Babeş-Bolyai University (Cluj-Napoca), Research Fellow at the \\ Sapientia Hungarian University of Transylvania (Cluj-Napoca, Romania) \\ E-mail: sandorkati@yahoo.com
}

\begin{abstract}
The paper discusses the question of media reflexivity and allegorical figuration in Lucian Pintilie's 1992 film, The Oak. Through a fictional narrative, the film reflects on the communist period from the historical context of the post-1989 transition strongly marked by the aftereffects of dictatorship and by political, social and economic instability. By incorporating a diegetic Polaroid camera and a home movie, The Oak displays a reflexive preoccupation with the mediality and the socio-cultural constructedness of the image. The figurative, allegorizing tendency of the film - manifest in the subversive recontextualization of grand narratives, iconographic codes or images of art history - also foregrounds the question of cultural mediation. I argue that by displaying the non-transparency of the cinematic image and the cultural mediatedness of the "real," the mediareflexive and allegorical-figurative discourse of the film can be regarded as a critical historical response to the social and representational crises linked to the communist era, but at the same time it may be symptomatic of the social, cultural, political anxieties of post-1989 transition. ${ }^{1}$
\end{abstract}

Keywords: Pintilie, The Oak, media reflexivity, allegory, intermediality.

In Romanian film history Lucian Pintilie's cinematic oeuvre can be regarded as an intriguingly transitional discourse. From a historical perspective, Pintilie is among the few Romanian directors whose work extends over the period of the Ceauşescu regime and post-communism. In state socialism, within the constraints of censorship, normative cultural policy and propagandistic film production, he experimented with the possibilities of dissident, socially critical, self-reflexive

1 This work was supported by a grant of the Romanian Ministry of National Education, CNCS UEFISCDI, project number PN-II-ID-PCE-2012-4-0573. 
cinema, ${ }^{2}$ then, in post-communism, he reflected on the altering socio-economic, cultural, and media-historical conditions of transition. The sensitivity of his oeuvre towards both social and cinematic actualities also marks his collaboration with the directors of New Romanian Cinema. ${ }^{3}$

After the 1972 banning of his stage adaptation of Gogol's Inspector General, Pintilie's exile and work in France enabled an in-between perspective, a travelling gaze between East and West European cultural contexts. This is particularly noticeable in his post-1989 films that reflect on an ambivalent transition (marked by the socio-political, institutional, and economic "heritage" of state socialism) to a more democratic system and a rapid (and uncritical) opening towards capitalist structures ${ }^{4}$ and the so-called Western world. Hajnal Király rightfully considers that Pintilie repeatedly adopts the somewhat self-othering "Outsider's gaze," using "Western art references - music, painting or sculpture - to ironically depict a post-communist Romanian society ignorant of individual dramas resulting from the collapse of industry, economy and infrastructure. He repeatedly thematizes institutional miscommunication, coexisting with a preference for Western cultural and civilisatoric forms without content” (Király 2016).

The in-betweenness of Pintilie's cinematic oeuvre is manifest not only in its historical and cultural aspect, but also in the aesthetics and politics of the image, in the inclination towards a quasi documentary gaze and media-reflexive practices and a more figurative, allegorizing discourse. ${ }^{5}$ While under state socialism allegories and parables could function as modalities of evading censorship and even of coding “dissident” messages (as in his 1982 Why Are the Bells Ringing, Mitică?), in Pintilie’s post-1989 films allegorical figurations may be symptomatic of social and representational crisis in which narratives and images of European cultural memory are revisited within the unsettling historical actualities of the transition period.

2 As in his films Reconstruction (Reconstituirea, 1969) and Why Are the Bells Ringing, Mitică? (De ce trag clopotele, Mitică?, 1982), both of which were banned before 1989.

3 As in The Afternoon of a Torturer (După amiaza unui torționar, 2001) with Cristi Puiu (as counselor, cf. http://aarc.ro/newfilm/film/dupa-amiaza-unui-tortionar-2002) and in Niki and Flo (Niki Ardelean, colonel în rezervă, 2003) with Cristi Puiu and Răzvan Rădulescu (as scriptwriters). Analyzing the cultural and socio-economic context of New Romanian Cinema, Hajnal Király underlines that "[t]he rapid advent of globalization after the change of regime triggered the inauguration of 'wild' capitalist structures on a faulty institutional infrastructure" due to the lack of social and political structures and of the practice of a civil society $(2015,173)$.

5 The presence of media reflexivity and allegorical discourse can already be observed in Pintilie's Reconstruction (1969). As Gorzo argues, "[t]he behavior of some characters [...] and the backdrop against which they evolve (through its elegant indetermination) are characterized by a certain allegorical stylization" (2013, 6-7). For the discussion of allegorizing tendencies in Pintilie's Why Are the Bells Ringing, Mitică? (1982), An Unforgettable Summer (O vară de neuitat, 1994), Too Late (Prea târziu, 1996), and Tertium Non Datur (2006), see Király (2010 and 2016). 
The Oak (Balanța, 1992), a French-Romanian co-production ${ }^{6}$ that marks Pintilie's directorial return in Romanian cinema after the end of the communist regime, literally performs an act of transition: through a fictional narrative, it reflects on the absurdities and traumas of the communist regime from the historical context of post-communism still strongly marked by the political and institutional legacy of dictatorship and by political, socio-economic and cultural instability. The protagonist of the film, the dissident Nela (played by Maia Morgenstern) seems to embody the provoking in-betweenness of Pintilie's filmic discourse: we see her carrying a Polaroid camera and - in a short scene - a funerary cross [Figs. 1-2], being figured both as an image and as a subject making and questioning images, both as a more abstract, allegorical body and as a discursively, socially uncontainable corporeality. Through adopting a photographic gaze and incorporating a diegetic Polaroid camera and a home movie, The Oak displays a reflexive preoccupation with the mediality and the socio-cultural constructedness of the image. The figurative, allegorizing tendency of the film - manifest in the subversive recontextualization of grand narratives and iconographic codes also foregrounds artifice and mediation. As Ismail Xavier argues, allegory "is a signifying process most identified with the presence of mediation, with the idea of cultural artifact that requires specific frames of reference to be read, quite distant from any sense of the "natural"' $(2004,333)$. By foregrounding the nontransparency of the cinematic image and the cultural mediatedness of the "real," the media-reflexive and the allegorical-figurative tendencies of the film "respond" to social, cultural and representational crises at a particular historical moment.

\section{Performing Reflexivity through Home Movie and Polaroid}

In Pintilie's films media reflexivity involves a critical approach to the medium which is foregrounded not only as the embodiment of an apparatus, technology or code, ${ }^{7}$ but also as a social practice implicating individuals, interpersonal negotiations, power relations, private and institutional contexts and modes of

6 The film is based on Ion Băieşu's novel, The Scales (Balanța, 1985). The censored version of the novel was published in 1985, the uncensored one in 1990. Băieşu co-scripted the film with Pintilie.

7 Cf. "A medium is not just a set of materials, an apparatus or code that 'mediates' between individuals. It is a complex social institution that contains individuals within it, and is constituted by a history of practices, rituals and habits, skills and techniques, as well as by a set of material objects and spaces (stages, studios, easel paintings, television sets, laptop computers)" (Mitchell 2005, 213). 
reception. Within this set of conditions, the technical apparatus does not merely record an intact, self-same reality, but intervenes into and constructs what counts as "real." 8 In The Oak, the incorporation of a fictional home movie and a diegetic photo camera within the film enables a reflexive approach to the question of mediation through disturbing the transparency of the cinematic image. Discussing the broader question of intermediality, Joachim Paech highlights the disruptive function of media reflexivity, arguing that in the case of cinema the mediality of the image is exposed by the "breaks, gaps, and intervals of the form processes" that "refer to the media conditions of their construction" (Paech 2000, emphasis mine, K. S.). These "breaks, gaps, and intervals" are observable in various instances of montage, superimposition, or framing techniques, as well as in "appearances or traces of materiality and dispositive construction which 'figure' in the film" (Paech 2000). ${ }^{9}$ However, the filmic discourse incorporating a photo camera and the projection of another film can be described not only through the figure of the break or gap, but also as a textural medial layeredness or fold (as it will be pointed out later).

In The Oak, home video and Polaroid photography ${ }^{10}$ are embedded into a particular socio-historical and media historical context within diegesis: the years before the end of the communist regime. The narrative infused with macabre irony and humor evolves around the dissident, outspoken, eruptive Nela, daughter of a former colonel of the Securitate (i.e. the secret police in communism). After the death of her terminally ill father, Nela is assigned a teaching job in the heavily polluted industrial town of Copşa Mică. Following a both apocalyptic and absurd train journey, she reaches the town where she is raped by a gang, being eventually saved by Mitică, a rebellious doctor (played by Răzvan Vasilescu) in the disastrous hospital of the town. The doctor (kept under surveillance by the Securitate) is imprisoned for striking a state official, but due to his professional

8 Media reflexivity has a historically changing critical function in Pintilie's oeuvre. Before 1989, in the context of the normative cultural policy of the totalitarian regime, cinematic reflexivity could function as a subversive act (as in Reconstruction) through unmasking the crisis of representation and the mechanisms of state-sanctioned propagandistic image production. After 1989, media reflexivity exposes the altered socio-cultural conditions and media practices of post-communism, for example, in Niki and Flo, see Sándor 2016).

9 The disruptive aspect and the critical function of media reflexivity is also underscored by András Bálint Kovács, who considers that reflexivity "creates a hole, [...] in the texture of the fiction through which the viewer is directly connected to the aesthetic apparatus of the fiction" (2007, 225). Reflexivity can function (especially in late modernism) not only as mere self-referentiality, but also as "a fundamental critical approach vis-à-vis the medium within which it is realized" (Kovács 2007, 225).

10 In the adapted novel The Scales (Balanța), Ion Băieşu does not mention either home video or Polaroid. These result from Pintilie's own intervention into the script. 
fame, he is released. Nela and Mitică - after the burial of a former patient of the hospital and a carnivalesque funeral feast in the countryside - bury the ashes of Nela's father under an old oak. The film ends with the couple witnessing how young soldiers massacre children and the rebels (or rather "desperados"11) who took them as hostages. Nela and the doctor return to the oak unsettled, bring up the possibility of having a child, and re-assert their rejection of (politically, socially) imposed normality.

According to Alex Leo Şerban, The Oak "unfolds by means of constant audiovisual embeddings and mise en abymes: home movies, Polaroid photos and reconstructed events from the past, culminating with the apocalyptic finale -itself a mise en scène" (Şerban qtd. in Nasta 2013, 99). The film begins with Nela and her dying father watching a home movie about a carnivalesque Christmas party from Nela's childhood: the little girl is filmed while playing with an unloaded gun and "exterminating" the adults who play dead for the sake of the game. ${ }^{12}$ [Fig. 3.] The Super 8 home video, the projector and the Polaroid camera in a fictional narrative set in the Romania of the late 1980s may recall the historical context of a political iconoclasm in which "[o]rdinary people's possession of film cameras - just like of any other type of communication technologies - was considered a subversive act and as such, suspicious in the eyes of those in power" (Blos-Jáni 2013, 89). Due to centralized market and state control, the possession and the use of film cameras or other communication technologies was related to social and economic tactics and to socio-political status within the system (BlosJáni 2013). In the film, the ownership of the projector, the home movie, and the Polaroid camera (even if the latter is at times used in a reflexive, critical way) marks a privileged social and political status within the regime ${ }^{13}$ (Nela's father is a former colonel of the Securitate). These apparatuses also function as fetishized, de-contextualized components of Western consumer culture. In a frame, the Polaroid camera is somewhat didactically displayed in a "still-life" composition

11 Caufman-Blumenfeld points out that the episode of the massacre is "based on a real, similar incident that took place near Timişoara airport" $(1998,270)$.

12 Dominique Nasta evokes Pintilie's remark that these scenes originate from his having had access to Ceauşescu's own home movies $(2013,100)$. In Gabriel Kosuth's documentary about the making of The Oak (Shooting [Filmare], 1992) Pintilie comments on the home movie scene and the girl playing little Nela as follows: "She is Zoia. This is what the relationship should look like" (Zoia is the name of Ceauşescu's daughter).

13 It is not the photo camera itself that alludes to social privilege, but the trademark (Polaroid) absent from the official market during state socialism. Unlike film cameras, photo cameras were largely available during the 1970s and 1980s. Although photography was a "national pastime," as Simina Bădică argues, it was also tamed into "a benign form of artistic expression" and withheld from becoming a means os social critique $(2012,45 ; 59)$. 
with a Marlboro shopping bag and Kent cigarettes [Fig. 4], all iconic products of American culture and synecdoches of capitalist consumerism, circulating in socialist Romania as a kind of unofficial currency that could "buy" or allude to social, economic privileges.

The scene of the daughter and the dying father watching the farcical home movie in a suffocating, dirty apartment infused with the sublimity of non-diegetic Wagnerian music is staged as an uncanny medial and corporeal experience. The helpless, dying body of the colonel and his present de-privileged status within the system is juxtaposed with the filmic image of his youth that reenacts the iconography of power as if paraphrasing official propaganda images of the communist dictator holding children in his arms and being surrounded by his entourage. [Fig. 5.] Moreover, the scene apposes in an ambiguous intimacy the dying father, a former representative of the regime with his dissident daughter, who rejects the same regime and, as a child, playfully "kills" the father and his entourage in the home video. ${ }^{14}$ The home movie is connected to an uncanny fold between the "real" and the carnivalesque play, ${ }^{15}$ life and death, past and present identities, (mediated) presence and absence. The body of the dying father becomes motionless, while the absent, mediated characters are animated, alive and perform death as a role. According to Laura Mulvey, the photographic index "reaches out towards the uncanny as an effect of confusion between living and dead" (Mulvey 2006, 319), between presence and absence, past and present, here and there. In Pintilie's film, the medial experience of watching the home movie is a continual displacement between still bodies and moving images, life and death, corporeality and technology, seeing, touching ${ }^{16}$ and being touched. [Fig. 6.] In terms of media reflexivity, the film projected within the film may disclose the medial-discursive conditions and the textural quality of the moving image. Within diegesis, home movie and the presence of the projector display a paradoxically both prosthetic and intimate contact between the medium and the body. The walls of the room are patterned by moving shadows and images that expose the (im)materiality of the projected home movie (and of the main film).

14 The ambiguity of the father-daughter relationship is also summed up by the sentence Nela utters when burying her father's ashes near the oak: "Tată bun, tată tiran, tată fricos.” ('Good father, tyrannical father, cowardly father.')

The home movie projected in the diegetic world also functions as a narrative mise en abyme prefiguring the merciless massacre of the children and the rebels at the end of the film. The amateur film about the familial past enters the diegetic present also through metalepsis, when a ringing doorbell seems to interrupt something both in the diegesis of the home movie and of the main film.

Nela is touching her dead/dying father's hand while watching his "lively" filmic image. 
The faces and the hands touching are "palpated" by the light and the shadows of the projector placed in the immediate proximity of the characters' bodies. The fictional, carnivalesque home movie, besides pointing to former socio-political relations of privilege (and reenacting the iconography of power), becomes the archival site of private memory and the medium of a both unsettling and intimate connection between father and daughter, past and present, image and body.

Polaroid photography is foregrounded in the film both as object and as practice, and is linked to the protagonist's perceptual, interpretive, documenting or critical acts of relating to the world. Thus, photography becomes an extension of the corporeal gaze, a prosthesis folding the technological into the corporeal and enabling a photographic vision that shapes the protagonist's way of seeing.

The cultural and media historical particularity of the Polaroid, "the photograph of attraction," ${ }^{17}$ as Peter Buse calls it $(2010,192)$, has been related to its instantaneousness, to the white frame and the limited size of the shot that display the act of segmentation, to the thingness of the photo as object, as well as to its practice as a social event of picture-taking that turns the camera into a sort of social catalyst (cf. Buse 2010, 194, 202). The idiosyncrasy of the Polaroid can also be linked to its hesitant, quasi nostalgic temporality between past and present and to its volatile chromatic aspect lingering at times between the photographic and the painterly. ${ }^{18}$

In The Oak, Polaroid photography discloses the reflexive concern of the film with image-making itself, while the immediacy of the photos resonates with the occasionally fast-pace editing of the film. The instantaneousness of the Polaroid enables the immediate reduplication and "othering" of the "real" through the medial which inscribes a relation of similarity and difference, of (irrecoverable) presence and absence in-between the "real" and its indexical trace. ${ }^{19}$ The constant use of the Polaroid camera by Nela and the frequent insertion of Polaroids into the frame impregnates the film with the awareness that the "real" is being framed, (re)constructed, mediated. On the diegetic level, the mise en abyme of the image within the image, frame within the frame exhibits the act of testing the difference of the photographic trace by comparing it to the "real" [Figs. 7-8],

17 As Buse explains: "the emphasis in its use is on the display of photographic technologies rather than the resultant image" $(2010,189)$.

18 As Hervé Guibert writes, the beauty and the force of the Polaroid "reside in the fact that it is something that has been disgorged, something hurried and fragile, and in its anguished race for immediacy, its backing away from time" $(2014,110)$.

19 This difference can be sensed, tested or "caught in the act" of picture taking, almost as in digital photography. 
but simultaneously it foregrounds the filmic image itself as an act of framing. The limited size and the pronouncedly framed aspect of the Polaroid displays a miniaturization of the "real" through scale reduction and framing, whereas the mise en abyme composition points to the excess of the "real" that escapes both the photographic and the filmic frame. Lúcia Nagib reflecting on Wim Wenders's The State of Things argues that the "reproduction of the real through gadgets and different artistic media is a means for the characters to come to terms with an overwhelming, crushing reality, which they fail to comprehend and to subject to their own ends" $(2014,193)$. In a somewhat similar way, when Nela uses the Polaroid camera, she attempts to relate to the incomprehensibility of the "real" through miniatures, through small size photographs. Mary Ann Doane ${ }^{20}$ (referring to Susan Stewart) argues that "[a]lthough the miniature appears completely intelligible and knowable, the gigantic... exceeds the viewer's grasp and incarnates the limited possibility of partial knowledge" (2009, 63). In Pintilie's film, the cinematic image of a monstrous industrial landscape, an embodiment of the forced industrialization of communism and of industrial modernity in general is juxtaposed with a less ambitious, miniaturizing Polaroid "leg selfie"21 as a perhaps (self-)ironic acknowledgment of an unframable excess.

The reflexive use of photography in (analogue) film may expose the photo not only as the medium of memory but also as the memory of the cinematic medium, a kind of technological or medial unconscious, disclosing what Mulvey considers the film's uncertain, unstable materiality "torn between the stillness of the celluloid strip and the illusion of its movement" $(2006,26)$. Through showing the few-second process in which the Polaroid develops, the film displays the becoming of an image, a medial event of difference [Figs. 9-10], foregrounding the photo as a figure of medial in-betweenness. The background of this medial occurrence is static, whereas the photographic image displays a short temporal process, as if figuring the volatile mediality of the cinematic in-between stasis and becoming. The Polaroid performs an act of becoming that is nevertheless archived and replayed through the filmic. Thus we see "not just an 'inscription' of one medium into another, but a more complex 'trans-figuration' taking place, in the process of which one medium is transposed as a 'figure' into the other, also

20 Mary Ann Doane relates the effects of the manipulation of scale on the spectator to the growth of capitalism and considers that it situates the subject "as epistemologically inadequate, as incapable of ever actually mapping or understanding the totality of social forces that determine his or her position" $(2009,63)$.

21 The "leg-selfie" also displays self-perception and self-representation as shaped by the fold of the photographic and the corporeal gaze. 
acting as a figure of 'in-betweenness' that reflects on both the media involved in this process" (Pethő 2011, 4).

In The Oak, the photographic act is also assigned a critical function of confronting the viewer with the "real" through its medial trace: the juxtaposition of the photo of the living calf and of the same calf killed during a military exercise is used by Nela to confront a bewildered soldier with the brutal sideeffect of military action. [Fig. 11.] Juxtaposing separate photographic images to generate meaning-making functions within diegesis as a reflexive, critical or as a humorous metaphorical act (e.g. a photo of Mitică juxtaposed with that of a calf [Fig. 12]), while as a meta-filmic figure it may foreground the relational aspect of the semantics of cinema, ${ }^{22}$ based on an indexical and iconic relation of the image to the "real" and to the viewer's previous media experiences, as well as on the relationship of one image to another manifest in the principle of montage.

The ambivalence of the (critical) photographic gaze and of Nela's dissidence is exposed by the fact that even if she rejects the totalitarian ideology of the regime, she is occasionally coerced to reproduce its objectifying mechanisms. After a failed attempt to save Mitică from prison, she uses the Polaroid camera in a farcical scene to stage an adultery and blackmail the prosecutor with photos of him naked. The fact that she "documents" an adultery that did not actually happen (being interrupted precisely by the photographic act itself), shifts the question of the (unstable) photographic proof towards the staged and de-contextualizing aspect of the photographic act. Nela reproduces the method of false evidence and blackmail (also used by the Securitate) through appropriating the indexicality of the medium. Her ambivalent dissidence points to the pervasive mechanism of totalitarian power that is partially interiorized and reproduced by the (dissident) subjects, who are coerced to imitate the strategies of power in order to make themselves heard. ${ }^{23}$

The ritual use of the photos by Nela in the burial scene reveals a quasi-naive, animistic, even archaic understanding of the image, according to which the photograph as an object and as a set of (social) relations becomes a replacement,

22 Cf. "The semantics of cinema is fundamentally relational. [...] Cinematic meaning is always contextual and signification relies on a set of relationships: the relationship of the image to the real world (its indexicality and iconicity: the way it resembles what we already know in the real world, and the way we magically interpret the image as the real world, etc.), the relationship of one image to another (meaning forged by the cinematic montage, the famous Kuleshov effect, for example), the relationship between the media constituents of the film, between the present film and our previous experiences" (Pethő 2011, 59).

23 In another scene, Nela tells Mitică (the other dissident and ambivalent character with both anti-authoritarian and authoritarian attitudes) how she reproduced a technique of punishment applied by the police on her: she used a hose with water jet to discipline the pupils at her school, commenting that at least she learned something from the police. 
a surrogate of the body. Nela attempts to detach herself from her sister (whom she considers a "filthy" Securitate agent), as well as from her chosen, talented pupils through burning and burying their photos.

In the film, Polaroid photography is exposed in its volatile mediality that resists essentialization. The instantaneousness of the Polaroid may enhance its malleability or adaptability to most differing uses, gestures, and social contexts. Polaroid works as a (reflexive) remediation or a critical intervention into the "real," as memory prosthesis, or as a social act of image-making, but also as an arbitrary appropriation of the "real." The photographic gaze as an extension of the corporeal one and photography as practice intertwine with the female protagonist's dissident, interpretive acts through which she relates to the world around her. Through exposing the act of looking and image-making, Polaroid and home movie are linked to the reflexive concern of the film with its own artifice and with the role of images in accessing, mediating, interrogating, and ultimately "carving for" the (immediacy of the) "real." Thus, in The Oak the reflection on absurd, disturbing realities from the recent communist past is performed through a fictional filmic discourse preoccupied with the historical, medial, and sociocultural conditions of representation itself.

\section{Allegorical and Intermedial Figurations}

Besides media reflexive practices, the presence of mediation is foregrounded in The Oak through an allegorical discourse that revisits grand cultural narratives and images whose dismantling or re-alignment may foreground the question of socio-cultural and representational crisis during the communist regime and the post-1989 period. In Ismail Xavier's understanding, allegory - as a figurative discourse that connects forms of representation and specific social conjunctures articulates "certain conceptions of human experience in time or an encompassing view of history in a condensed way" through personifications, juxtapositions, given models, iconographies, or narrative patterns $(2004,361)$. The figurative tendency of Pintilie's film is marked by the historical shift of emphasis that characterizes modern and postmodern allegory. According to Xavier, "allegory has acquired a new meaning in modernity - more related to the expression of social crisis and the transient nature of values, with special emphasis given to its connection with the sense of the fragmentation, discontinuity, and abstraction” $(2004,360)$. Xavier considers that allegory can point to the crisis of representation characteristic of "periods of transition and accelerated technical-economic changes which enforce 
people to revise their views of identity and shared values" (2004, 359-360). The Oak was released in an ambivalent, unsettled transition period in which economic and political instability, the crisis of (collective) identity, as well as the sociopolitical, economic, and cultural "heritage" of the recent period of dictatorship called for the renegotiation of previous meanings and modes of representation.

In The Oak the allegorical tendency is manifest in narrative patterns that subversively recontextualize biblical motifs, interrogating the validity of grand narratives (or shared values). The brutal extermination of the children and the rebels at the end of the film might recall the motif of the Massacre of Innocents, and the image of the oak with the two dissident, "untamable" protagonists might refigure the iconography of the primordial scene of the first couple. ${ }^{24}$ This scene is staged in the film as a sort of shadow image or quasi-monochrome sequence: due to the direction of the light, the colors and nuances are erased and the characters appear as shadows in front of a sepia background. The transparency of the image is suspended through a subtle medial opacity; the scene unfolds as abstract, twodimensional and pronouncedly theatrical, as an aestheticized spectacle that might favour an allegorical approach to the image.$^{25}$ [Fig. 13.] Moreover, Nela's journey, her dissidence and her intention to change the status quo (e.g. to intervene into the uniformizing practice of an ideologically appropriated education system $^{26}$ ) may reenact the narrative of an anarchist, resistant savior or rebel.

Doru Pop implicitly situates Nela's rape within an allegorical framework, arguing that The Oak deals with rape not only as "symbolically charged social criticism, but also as a liberating path" $(2014,200)$. The rape, unsolved by the militia, "is a reference to the social rape made acceptable by the Communist regime” (Pop 2014, 200). This interpretation seems to allegorize Nela's body conceiving it as a more abstract, discursive body: the corpus of a society or nation "violated" by the oppressive mechanisms of the regime. Nevertheless, in the film as a whole, Nela's character and corporeality retain an unincorporable otherness, invalidating unequivocal discursive categories or oppositions, such as victim

24 As Dominique Nasta underlines, Pintilie himself has described the epilogue "as yet another variant, following Reconstruction, of the biblical Massacre of the Innocents" (2013, 102).

25 However, the previous scene of burying the father's ashes next to the tree displaces allegorical reminiscences through a more secularized, profane corporeality and through the ironic contamination of cultural codes: the cremated body of the father (a colonel with an ambivalent past in the communist regime) is transported in a Nescafé bottle, a synecdochic "container" of the Western world.

26 However, Nela's project is somewhat contradictory: on the one hand, she tries to reject ideologically embedded uniformization and normalization through selecting talented pupils to teach them separately ("collecting" them as the members of a chosen group captured through Polaroid). On the other hand, she creates a segregated group rejected by their own fellows. 
versus an oppressive regime (she cannot entirely escape the mechanisms of the repressive system she rejects).

Nela is not containable within the concept of passive victimhood or appropriated corporeality: she seems to be able to distance herself from her own body similarly to the way she perceives the world through a photographic gaze that performs an act of reflexive detachment. The photographic gaze merging the technological into the corporeal might become a prosthetic mode of both perception and self-perception. Nela's detachment from the traumatic event of the rape could apparently be explained through the dissociation model that emphasizes the inaccessibility of trauma: the experience of trauma is so overwhelming and entails such a disruption and alienation within the self that it cannot be uttered, dealt with or cognitively processed. Instead, it is delayed, split off, and engraved as a special from of "bodily memory" that "ends up only leaking its disturbing and ambivalent traces in the typical traumatic symptoms of flashbacks, hallucinations, phobias, and nightmares" (Kaplan-Wang 2004, 5). After being physically punished by the police, Nela's taking a handful of pills could be related, among others, to the delayed corporeal eruption of this unprocessed trauma. Nevertheless, her traumatic experience cannot be explained through the dissociated self alone. Nela, empowered with irony, agency and assertiveness, is able to reassemble her identity against power abuse, trauma or appropriation. After being raped, she falls asleep at the police station while the officer interrogates her. Kata Kiss, discussing later films, considers that the ability of female characters (like Mona in Szabolcs Hajdu's Bibliothèque Pascal and Grace in Lars von Trier's Dogville) to fall asleep after a traumatizing event displays a particular kind of resistance since the sleeping body is the most vulnerable, but at the same time sleep enables a most autonomous state of subjectivity (Kiss 2011, 53). Even though Nela is raped, her body and subjectivity remain within a vulnerable, exposed, yet resistant otherness that is beyond the containable. ${ }^{27}$ Her corporeality does not coincide either with mere biological givenness ${ }^{28}$ or with socially validated (patriarchal) norms of femininity, since she persistently interrogates such patterns. Thus, embodiment means a continual negotiation between discursive, social relations (of control) transcribed onto the interpretable body and a more uncontainable corporeality that exceeds the social and the discursive.

27 Mitică senses the traumatic and does not approach or touch her until the last scene of the film, when they embrace each other.

28 The body never coincides with itself as a biological entity, "never achieves a stable identity, being continually shaped by historical and cultural systems" (Madison quoted in Sobchack 2004, 4). 
Along with narrative allegorizing tendencies, "the presence of mediation" (Xavier 2004, 333) is also manifest in intermedial figurations that reenact the optical regime of other media or paraphrase individual paintings of the Western canon, performing an iconographic anamnesis through the film medium. In her study about the reconceptualization of tableau vivant in contemporary East European cinema, Ágnes Pethő - besides linking cinematic tableaus to the desire of objectification, of becoming an image in recent artistic practices - interprets the tableau as a figure of return in Lyotardian terms. According to Pethó, postpostmodern films that tackle with universal themes and refer to art history and Christian imagery through tableaux vivants or tableau compositions can be viewed as metafictional allegories of the "urge for reconstruction, reinstatement, and reembodiment of myths" $(2014,69)$, as attempts "to open up the small, local, often minimalist narratives through the insertion of the 'grand image' towards equally grand (biblical, archetypal, mythical) narratives"29 (2014, 67). Nevertheless, the tableau vivant may also perform "paradoxically, a movement of 'détournement,' both by placing the cinematic image into the much less stable 'shadow of the arts,' and by consistently counterpointing the aestheticism of the tableau constructions with a subversive emphasis on bodies and senses" (Pethő 2014, 69). The productive tension of Pintilie's film is brought about - among others - by this bifold movement of return and détournement: grand (biblical, mythical) narratives, images or iconographic codes of European cultural memory are subverted by the ironic (and at times carnivalesque) discourse of the film, or are imploded by the corporeal that escapes allegorical, aestheticizing modes of representation.

In the film, Nela as an image is often framed by spatial figurations such as the space of a train compartment, the straight lines of the railway, grids, or door frames. Here the film image does not necessarily reenact a particular work of art through a cinematic tableau vivant; it rather remediates conventions, techniques, (iconographic) codes, compositional patterns pertaining to a specific (visual) art form. The train compartment rhythmically lit by moonlight, and "artificially" by the light of a cigarette, becomes (for a short while) a space of artifice and aestheticization framing a chiaroscuro spectacle: Nela's face seems to be "painted" on a dark background, counterpointing the rough reality of the train journey.

29 Cf. According to Pethő, the favorable reception of contemporary East European cinema in the Western festival circuit may be connected to the fact that "universal themes, references to art history and Christian imagery can be expected signs of sophistication" for Western audiences that associate these films with art house cinema. Therefore, "these easily recognisable references can facilitate connections to a wider cultural and artistic heritage perhaps as manifestations of a self-colonizing instinct" $(2014,64)$. 
[Fig.14.] Her image with a hamster framed by the door case [Fig. 15] might evoke and simultaneously displace pictorial conventions of portraiture from art history in the context of Romanian actualities from the late 1980s. Whereas the inscription on the frame reinforces the conventions of portraiture (framing Nela as a sort of dissident "lady with a hamster"), the meaning of the text ("place for banging your head') as a possible commentary on existential and social actualities ironically unframes the image and disturbs the aestheticizing potential of the frame.

Nela's figure is also inscribed by the iconographic codes of a subversively recontextualized Christian imagery. Following Titi's coffin, a former young patient of the hospital and self-proclaimed "apostle" of a new moral order, the atheist Nela carries the funerary cross and Titi's "scripture," a blue notebook. [Fig. 2.] This gesture and her one-person resistance to oppressive structures, imposed normality and power abuse displace the Christian narrative of the savior towards a secular and feminine perspective. Moreover, the grotesque scene in which the car transporting the coffin breaks off and the coffin accidentally opens, favors the carnivalization ${ }^{30}$ of cultural codes and the (temporary) fluidization of socially, politically codified roles and identities: the atheist Nela, wearing Mitică's clothes, carries the cross, the caricaturized Securitate agents change their roles by giving up surveillance and carrying the coffin of the trailed person. The allegorizing, carnivalesque tendency of the film manifest in the subversive reconceptualization of narratives and (cultic) images of European cultural memory is further reinforced by the scene in which twelve participants, assembled as a "collage" of social classes and roles (teacher, doctor, secret agent, priest, mayor, villager), attend the quite profane funeral feast and drinking party after Titi's burial in a room straightforwardly decorated with a cheap reproduction of a copy of Leonardo's Last Supper (1494-1498) and a fragment of an Orthodox icon.

However, Nela as an image remains uncontainable both within iconographic or aesthetic "frames" and within the socially acknowledged concepts of femininity. When she consciously uses stereotypical requisites of male fantasies of femininity (e. g. femme fatale or prostitute "accessories") to seduce and blackmail the prosecutor, her masquerade seems to evade objectification: she both constructs and detaches herself from an appropriating "image" of femininity. ${ }^{31}$ The way

30 The carnivalesque shapes Pintilie's filmic discourse both thematically and conceptually, being related in film criticism (cf. Király 2010, Pop 2014) to the literary and cultural legacy of Ion Luca Caragiale (1852-1912), a Romanian playwright whose work is associated with a particular dark humour, irony and social criticism.

31 Nevertheless, the use of the femme fatal and the prostitute clichés for blackmail does not radically contest their stereotyping mechanism but partially relies on it. 
Nela posits her own corporeality displaces the possessive gaze, and she resists being fetishized as inert surface, as mere "to-be-looked-at-ness" (Mulvey 2006). She situates herself as the subject of looking through her acts of photographic intervention and through the reflexive relation to her own body. Through her commentary and her defiant, de-eroticizing gesture of casting her naked leg on the table where male filmmakers discuss movies, the film critically unmasks the cinematic fetishization of the female body, its fragmentation and reduction to body parts. The same assertiveness directs her de-fetishizing gesture when, after being raped, she forcefully casts her naked leg on the table in the cabinet of the nonconformist doctor, Mitică - asking for a shoe. Her leg covered with dirt disrupts the imagery of the female leg as fetish and dislocates the possessive gaze.

The allegorizing, figurative tendency in the narration of Nela's story and in the construction of her image is continually disturbed by the eruption of the corporeal into the discursive regime of the allegorical. The dirt on Nela's body is not disturbing in itself. The dirty body is unsettling in social contexts in which it marks the displacement of a boundary and remains an excess that is unincorporable by existing normative categories or socially disciplined bodies. Elizabeth Grosz, discussing Mary Douglas's concept of dirt and impurity, underlines that "[n]othing has the intrinsic property of disrupting or disturbing, but can only be regarded as such in a specific context and system where order is imposed at the cost of the elements being thus ordered" $(1994,192)$. Dirt marks "a site of possible danger to social and individual systems, a site of vulnerability insofar as the status of dirt as marginal and unincorporable always locates sites of potential threat to the system and to the order it both makes possible and problematizes" (Grosz 1994, 192). The dirt on Nela's body imploding the concept of socially disciplined corporeality is also related to the dirt in her father's apartment, to her drinking dirty water from a vase, as well as to her intimacy with the sphere of the animalistic that contests the cultural hierarchy of human and non-human (she shares her apple with a hamster). All these corporeal transgressions point to something that is unincorporable and threatens socially consolidated control, exposing Nela's ambiguous resistance and sensitivity not only as conceptualideological, but also as disquietingly corporeal.

In The Oak, the body becomes a site where figurative, allegorical modes of representation intersect socio-political contexts and the excess of the corporeal. The image of Titi's dead body, the former patient of the hospital and self-declared "apostle" of a new religion, ${ }^{32}$ is incorporated into clinical space in which the

32 As it is stated in his blue notebook, he also "plans" a vegetarian and (somewhat) Spartan school 
(corpo)real is articulated at the intersection of the disturbing actualities of a dictatorial regime and the broader interpretive context of European cultural memory. The hospital, which in Foucauldian terms is a space for the discursive, institutional, socio-political control of the body and the subject, appears in the film as a dilapidated and dysfunctional institution where surveillance is performed not only by the clinical gaze but also by the all-pervasive institution of the secret police. Socially, politically uncontainable patients, such as Titi, and the rebellious doctor, Mitică, who defies institutional hierarchy and bureaucracy, are continually situated at the intersection of different, politically informed controlling gazes. Thus, the hospital is exposed in the film as a heterotopic space (Foucault 1986) in which faulty, dehumanizing institutional practices intersect the absurd power mechanisms of a totalitarian regime.

The "apostle's" dead body filmed from a static, frontal camera position and exposed in its fragile horizontality might evoke - in a conceptual rather than pictorial manner - representations of Christ that foreground his humanized, carnal existence. ${ }^{33}$ The image of the dead body suspended in-between allegorical meaning and the non-meaning of carnal corporeality is displaced towards the secular and the corporeal; behind the frail corpse, a door frames another image, that of random naked dead bodies lying on the floor as cadaverous flesh unredeemed by allegorical codes. [Fig. 16.] Staging the dead body of the socalled "apostle" in a dysfunctional Romanian hospital from the late 1980s may ironically confront the (in)validity of grand or utopian narratives (and ideologies) of redemption with the context of unsettling historical realities. Moreover, the image of the corpse as a hesitant figure oscillates between allegorical allusion and mundane, corporeal laughter (e. g. the nurse lights a candle for the dead Titi, then hides his "apostolic" blue notebook in her large underpants where the Securitate will not supposedly find it; she also prepares the body for funeral, displacing the institutional, clinical practices towards human intimacy and traditional funerary rituals). The subversive contamination of cultural codes exposing the mediatedness and the heterogeneity of the "real" along with the continual disruption of the allegorical by the corporeal (and at times by the carnivalesque) may point to a historically embedded social and representational crisis, as well as to the way collective or individual trauma and crisis - besides

for his future disciples.

33 E. g. Hans Holbein the Younger's painting, The Body of the Dead Christ in the Tomb (15201522). Julia Kristeva connects the melancholy of Holbein's painting to the isolation and solitude of the figure which she interprets as humanized, carnal and yet indecipherable, detached from pathos and from the promise of resurrection (Kristeva 1989). 
revealing "the bankruptcy of the prior symbolization" - "intensifies the urgency of re-symbolization” (Kaplan-Wang 2004, 14).

\section{Coda}

In The Oak, both the media-reflexive and the allegorical, figurative discourse foreground the artifice of the film and disclose the medial and socio-cultural conditions of image-making. The allegorical, figurative tendency is manifest in narrative constructions or intermedial figurations that subversively recontextualize familiar narratives and images of European cultural-iconographic memory. Released in 1992, the film - through its reflexive preoccupation with the "presence of mediation" - may critically point to the role of images in accessing, questioning, and (re)assembling the narratives of the recent past. Ismail Xavier underlines that "[t]he dynamics of allegory, with its typical dialectics of fragmentation and totalization, is far from a closed system; rather it is a signifying practice deeply involved in, and formally permeable to, the vicissitudes of historical change" $(2004,361)$. The allegorizing discourse of The Oak does not reinstate semantic, ideological or aesthetic totality, but rather it is articulated in the productive tension between allegorical figuration and de-figuration, between acts of remembering and dismembering cultural-iconographic memory. The process of allegorical and intermedial displacements in the filmic discourse can be regarded as symptomatic of the social and representational crisis linked to the period of dictatorship, but at the same time it may be a critically reflexive response to the cultural, social, political anxieties of post-1989 Romania marked by the (economic, socio-political, institutional) legacy of the communist era.

\section{References}

Bădică, Simina. 2012. Historicizing the Absence: The Missing Photographic Documents of Romanian Late Communism. Colloquia. Journal of Central European History vol. XIX: 40-62.

Blos-Jáni, Melinda. 2013. Men with the Movie Camera between 1945 and 1989.

Domesticating Moving Image Technology under Communism. Martor no. 18: 77-92.

Buse, Peter. 2010. The Polaroid Image as Photo-Object. Journal of Visual Culture vol. 9. no. 2: 189-207. 
Doane, Mary Ann. 2009. Scale and the Negotiation of 'Real' and 'Unreal' Space in the Cinema. In Realism and the Audiovisual Media, eds. Lúcia Nagib and Cecília Mello, 63-81. Basingstoke, Hampshire: Palgrave Macmillan.

Caufman-Blumenfeld, Odette. 1998. The Oak: A Balancing Act from Page to Screen. Film/Literature Quarterly vol. 26. no. 4: 267-278.

Foucault, Michel. 1986. Of Other Spaces. Diacritics vol. 16. no. 1: 22-27.

Gorzo, Andrei. 2013. Concerning the Local Precursors of the New Romanian Realism. Close Up. Film and Media Studies vol. 1. no.1: 4-12.

Grosz, Elizabeth. 1994. Volatile Bodies. Toward a Corporeal Feminism. Bloomington and Indianapolis: Indiana University Press.

Guibert, Hervé. 2014. Ghost Image. Chicago and London: The University of Chicago Press.

Kaplan, E. Ann and Ban Wang. 2004. Introduction. From Traumatic Paralysis to the Force Field of Modernity. In Trauma and Cinema. Cross Cultural Explorations, eds. Kaplan, E. Ann and Wang, Ban, 1-22. Hong Kong: Hong Kong University Press.

Király, Hajnal. 2010. Könyv és film között. A hüségelven innen és túl. [Between Book and Film. Beyond the Fidelity Principle.] Kolozsvár: Koinónia.

Király, Hajnal. 2015. Leave to Live? Placeless People in Contemporary Hungarian and Romanian Films of Return. Studies in Eastern European Cinema vol. 6. no. 2: 169-183.

Király, Hajnal. 2016. Looking West: Understanding Socio-Political Allegories and Art References in Contemporary Romanian Cinema. Manuscript, forthcoming in Acta Universitatis Sapientiae: Film and Media Studies.

Kiss, Kata. 2011. Az identitásszörny, a szent mártír és az ellenálló. Férfi versus női prostituáltak a kortárs magyar filmben. [The Identity Monster, the Saintly Martyr, and the Resistant. Male versus Female Prostitutes in Contemporary Hungarian Cinema.] Metropolis no. 3: 42-54.

Kovács, András Bálint. 2007. Screening Modernism: European Art Cinema, 1950-1980. Chicago and London: The University of Chicago Press.

Kristeva, Julia. 1989. Holbein's Dead Christ. In Black Sun. Depression and Melancholia, 105-138. New York: Columbia University Press.

Mitchell, W. J. Thomas. 2005. Addressing Media. In What Do Pictures Want? The Lives and Loves of Images, 201-221. Chicago and London: The University of Chicago Press.

Mulvey, Laura. 2006. Death Death 24x a Second. Stillness and the Moving Image. London: Reaktion Books. 
Nagib, Lúcia. 2014. Reflexive Stasis, Scale Reversal and the Myth of Modern Cinema. In Inert Cities: Globalization, Mobility and Suspension in Visual Culture, eds. Stephanie Hemelryk Donald and Christoph Lindner, 187-201. London: I. B. Tauris.

Nasta, Dominique. 2013. Contemporary Romanian Cinema. The History of an Unexpected Miracle. London and New York: Wallflower Press - Columbia University Press.

Paech, Joachim. 2000. Artwork - Text-Medium. Steps en Route to Intermediality. http://www.uni-konstanz.de/FuF/Philo/LitWiss/MedienWiss/Texte/interm. html. Last accessed 15. 02. 2011.

Pethó, Ágnes. 2011. The Passion for the In-Between. Cinema and Intermediality. Newcastle upon Tyne: Cambridge Scholars Publishing.

Pethő, Ágnes. 2014. The Tableau Vivant as a "Figure of Return" in Contemporary East European Cinema. Acta Universitatis Sapientiae: Film and Media Studies vol. 9: 51-76.

Peucker, Brigitte. 2008. Tableau Vivant in Film: Intermediality and the Real. In Intermedialität - Analog/Digital. Theorien - Methoden Analysen, eds. Paech, Joachim and Jens Schröter, 291-300. München: Wilhelm Fink Verlag.

Pop, Doru. 2014. Romanian New Wave Cinema. An Introduction. Jefferson: Mcfarland \& Company, Inc. Publishers.

Sándor, Katalin. 2016. Filming the Camera - Reflexivity and Reenactment in Lucian Pintilie's Reconstruction (1969) and Niki and Flo (2003). Manuscript, forthcoming in The New Romanian Cinema, eds. Stojanova, Christina and Duma, Dana. Edinburgh University Press.

Sobchack, Vivian. 2004. Carnal Thoughts. Embodiment and Moving Image Culture. Berkeley - Los Angeles - London: University of California Press.

Xavier, Ismail. 2004. Historical Allegory. In A Companion to Film Theory, eds. Toby Miller and Robert Stam, 333-362. Oxford: Blackwell Publishing. 


\section{List of Figures}

Fig. 1. Nela with the Polaroid camera. Fig. 2. Nela carrying the cross.
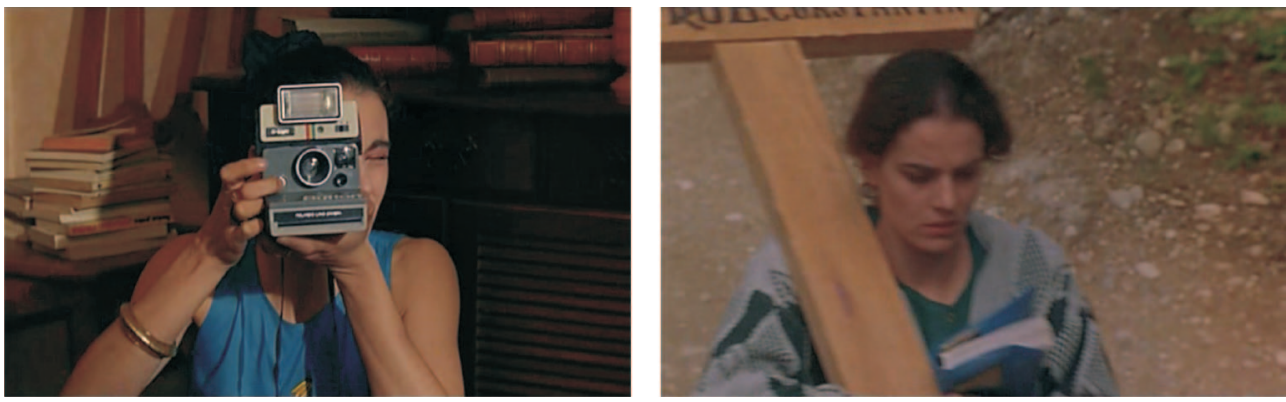

Fig. 3. The carnivalesque home video of Nela's childhood. Fig. 4. Synecdoches of American (consumer) culture on display.
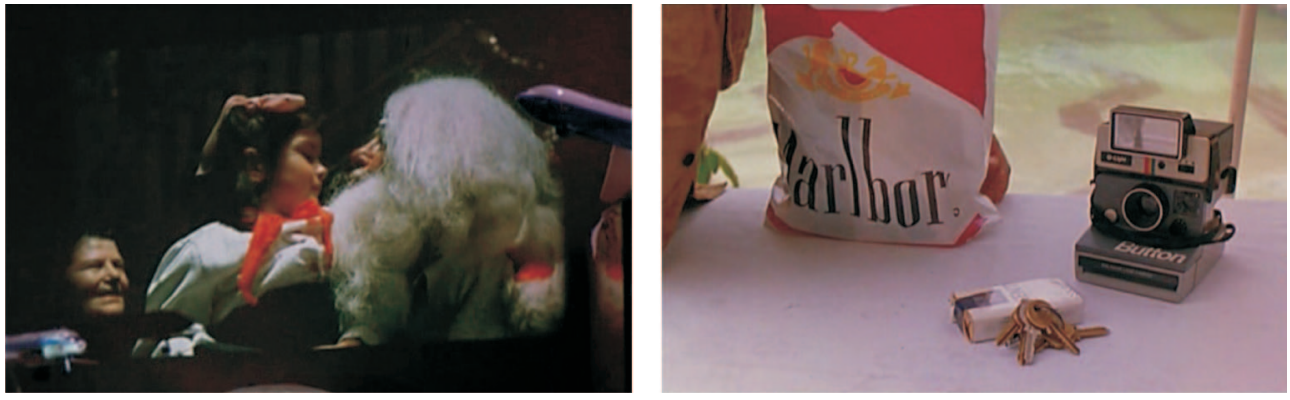

Fig. 5. Reenacting the iconography of power. Fig. 6. Seeing, touching and being touched.
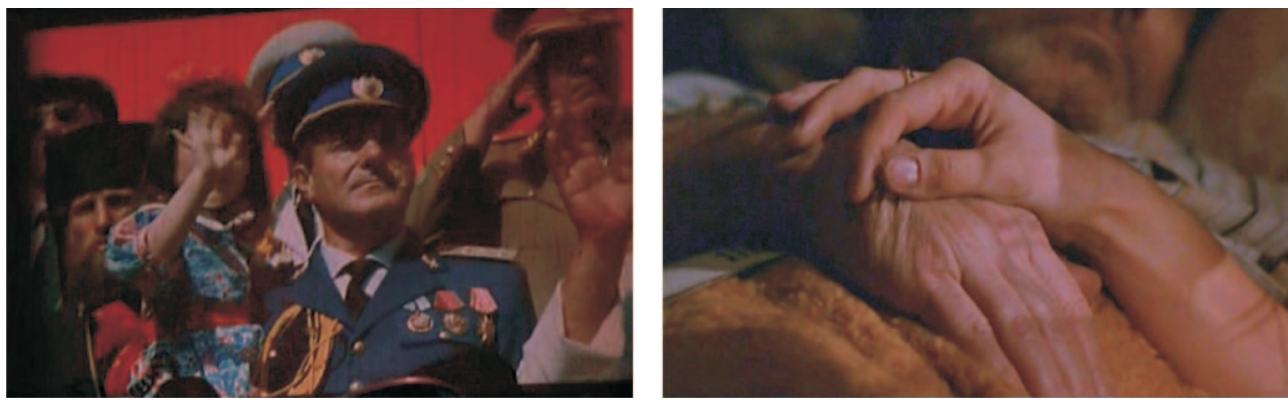
Figs. 7-8. Framing and miniaturizing the "real."
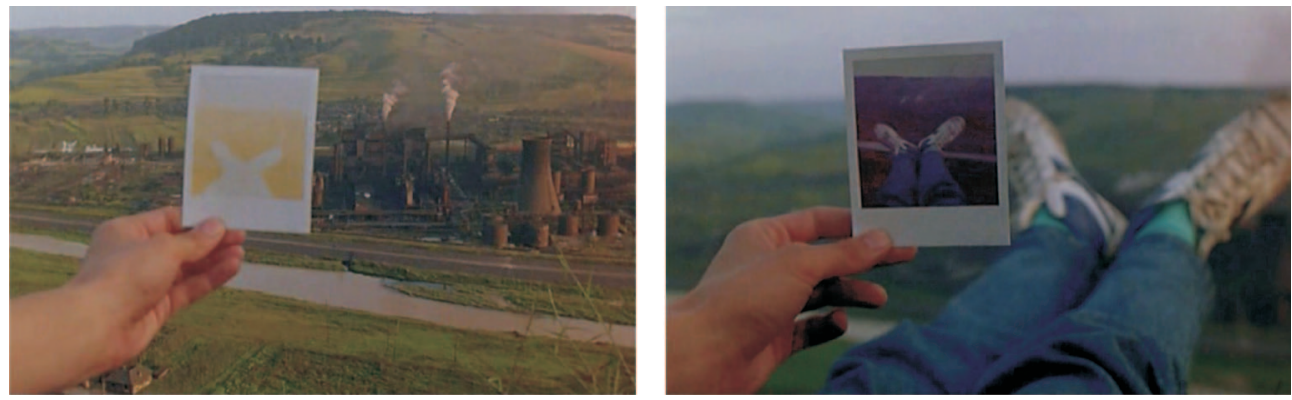

Figs. 9-10. (The) becoming (of) a Polaroid.
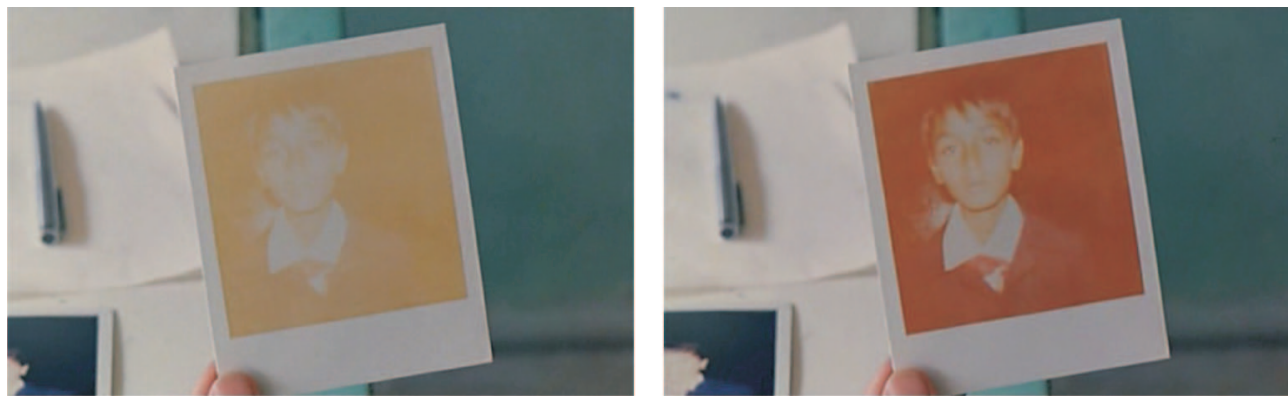

Fig. 11. Facing the "real" through the medial. Fig. 12. Making meaning through juxtaposed images.
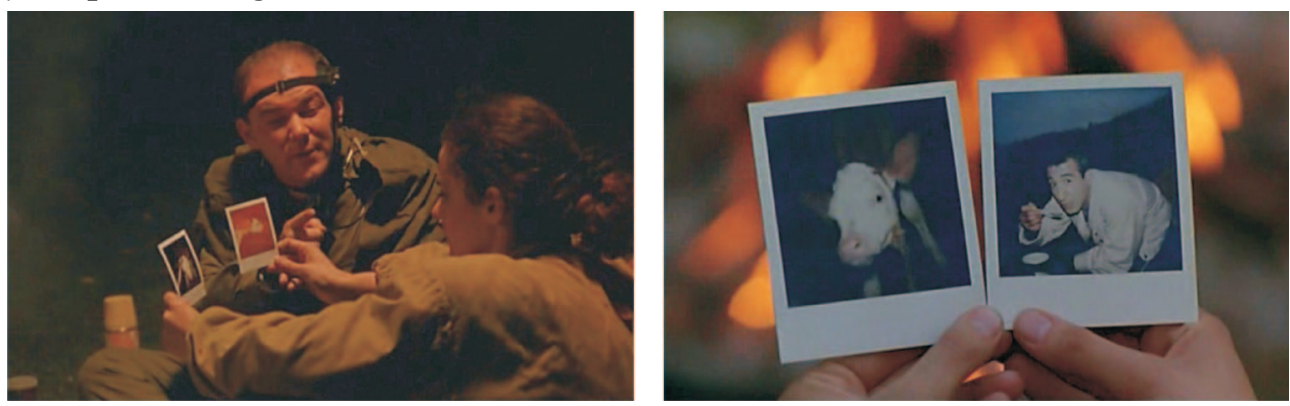
Fig. 13. "Shadow image." Fig. 14. Chiaroscuro spectacle in the train.
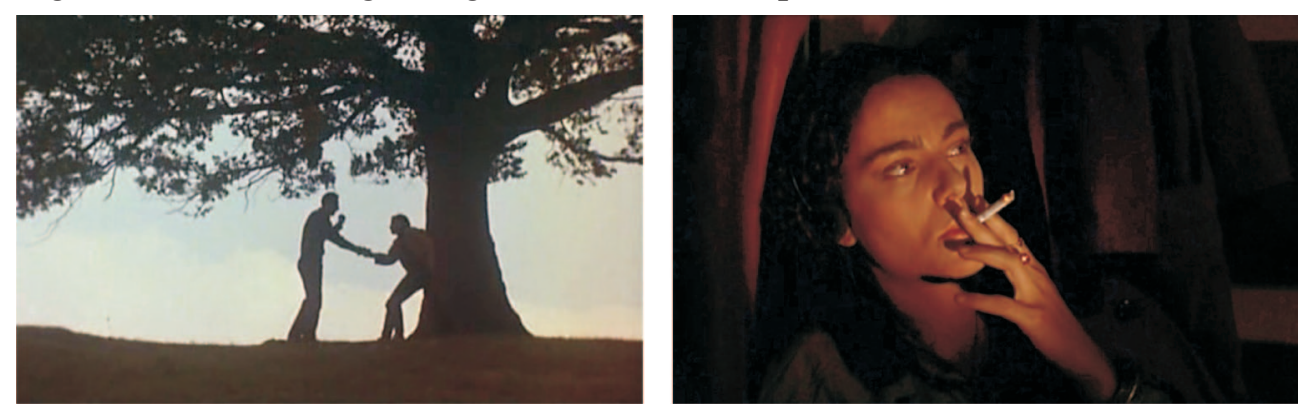

Fig. 15. Nela framed as "lady with a hamster." Fig. 16. The "apostle's" corpse.
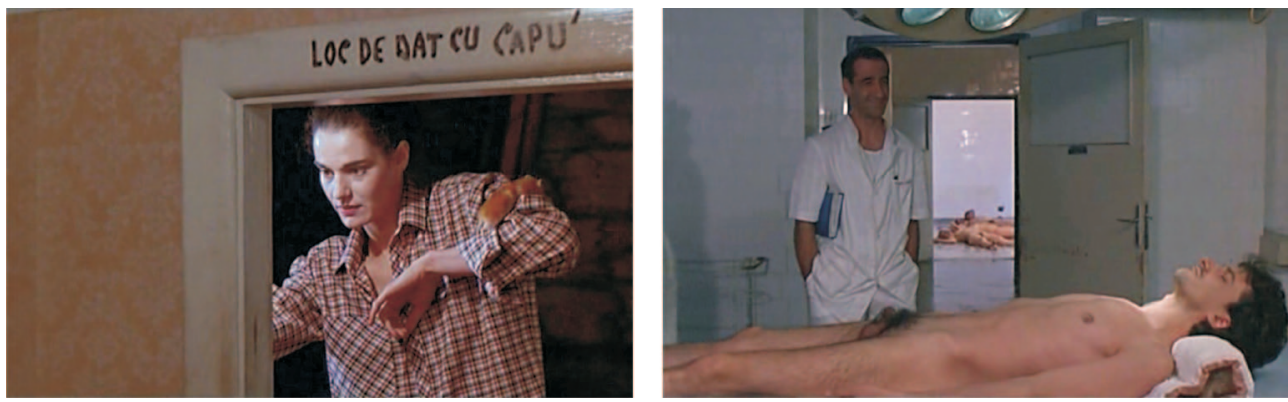